\title{
TRANSLATION OF NEGATIONS IN PRAMOEDYA ANANTA TOER'S NOVEL BUMI MANUSIA AND IT'S PEDAGOGICAL IMPLICATION
}

\author{
Ulin Ni'mah Rodliya Ulfah \\ English Department STAIN Kediri \\ (turusgurah@gmail.com)
}

\begin{abstract}
This study is aimed at (1) identifying the kinds of Indonesian negation found in Bumi Manusia which are translated into English; (2) analyzing the various strategies used by the translator to translate negations in the novel Bumi Manusia into English; and (3) evaluating the appropriateness of the translation of negation from Indonesia into English and describing its pedagogical implications. This study uses a descriptive-qualitative research design. The data of the research are negations found in three chapters (chapter 1, 3, and 5) of the novel Bumi Manusia and in their translation This Earth of Mankind. The result shows that of the 69 pages of the novel BumiManusia, 329 negation in simple sentences are identified. They are divided into three types: standard negation, negation and adverb, and negation and quantity. In translating the Indonesian negation in the novel BumiManusia, this study finds that strategies which have been applied are adopted from the seven strategies proposed by Newmark. Of 329 negation, 205 or 62.3\% dominantly applied the strategy of reproducing or adopting the same image of negation in the TL text. In relation to the evaluation of the translation appropriateness, the result shows that from 329 negation 308 or $93.6 \%$ are translated appropriately. Meanwhile, 19 translation of negation or $5.8 \%$ are categorized as less appropriate translation, and 1 translation of negation or $0.3 \%$ is rendered inappropriately.
\end{abstract}

Key Words: Translations, Negations, Translation Appropriateness, Negation Translation strategies.

\section{INTRODUCTION}

In having interaction each other, people mostly deal with sentences. However, composing sentences is not always simple, because it cannot be neglected that composing a sentence will relate too much to the structure or syntax. Syntax plays an important role, since it deals with conveying meaning through sentences. Haegeman (2005:
2) states that one of the core principles of generative syntax is the idea that syntax is structuredetermined. It show us that the principles to make a good sentence lie in syntax.

However, in having communication with others, people do not always agree with the other opinions. Sometimes, they express negation as they have different point 
of view. Toyyibah (2005: 1) says that the main function of negation is to deny or to disavow statement(s) of addressee or addresser considered wrong by the addressee. It means that related to the function of language as a means of communication, in any language negation plays a very important role.

Further, Sudaryono (1993: 1)sttes that such linguists as Lehnman (1973), Bloomfield (1993), Greenberg (1963), Langaker (1972), and Payne (1985) propose that negation is universal. The universality of negation shows that in any language, its existence plays an important role. Furthermore, Sudaryono (1993: 22) sys that the application of negation theory in some languages in the world shows that there are differences in both the expression system of negation and the grammatical unit used to express the negation.

According to Payne (1985) as cited by Sudaryono (1992: 16) klima's concept about negation has been tested to several languages other than English, they are Dutch by Kraak (1966) and Arabic-Iraqy by Bakir (1970). Based on the studies, Payne needs to enlarge Klima's concept about kinds of negative constituent into five types; they are, (i) standart negation, (ii) negated quantifier, (iii) inherently negative quantifier, (iv) negated adverbial, and (v) inherently negated adverbs.

In Indonesian and in English, negation I also expressed differently. Indonesian and English have different system of negation, not only in terms of negative devices used to express the negation but also their distribution in sentences. However, in Indonesia, English is also considered as a foreign language, which means that it isn't used in a daily communication. That's why it is not strange if many Indonesian people cannot speak English. The inability to use English is not a big problem since they can interact with their community in their countries. But the problems arise when they have to deal with people who cannot speak Indonesian and tend to use English as it is already known that English is considered as an international language, which is used as an international means of communication.

Problems seem to appear nit only in spoken but also in written form. Many books which contain of essential knowledge are written in English. If people do not know English, they cannot get the idea of the books. In the other hand, Indonesian people cannot just write their books in Indonesia. They need English to explore their knowledge in written form to make people (outside Indonesia who understand English) gain the point from what they have written. So, it can be said that people need English as a bridge to communicate with other people from countries in form written or orally. In other words, sometimes, translation is needed so much.

Translation is not merely substitution of the words from one 
language to another. According to a Newmark (1988: 7) translation is a craft consisting in the attempt to replace a written message and/or statement in one language by the same message and/or statement in another language. Translation is not an easy task since it involves the text, the meaning of the text, and the process of adapting the meaning to make it acceptable an natural in the target language by keeping the message or the content. Furthermore, Tursini (2007:2) says that translators will face more challenges when translating literary text such as novels, drama, short stories, and poetry since they should have a solid understanding of both the source text and the resources available in the receptor language, combined with the artistic competence.

However, among the studies of translation, few of them analyze the syntactic of negation. Toyyibah (2005) analyzed the syntactic negation of Arabic and English in the Holy Qur'an and its translation in English found that the Arabic negative devices used in the Qur'an are la, ma, lam, laysa (all of them mean not), lamma (not yet), lan (will not), and lata (no longer), and the English negative devices are not, no, never, almost not, cease not, and hardly. Semantically, the same negative device in differet sentence pattern may negate different elements in the sentence although they commonly negate the whole proposition. There arethree pairs of double negation in-illa, la-illa, and ma-min-illathat only occur in verb less constructions and function to express strong emphasis on a given proposition.

Another study was done by Tursini (2007) entitled The Translation of Figures of Speech in the Novel BumiManusia from Indonesian into English. On her study she found that the novel BumiManusia contains of 375 figures of speech which can be divided into simile, metaphor, personification, hyperbole, and idiom. From all of the translation of those figures, 358 $(95.5 \%)$ of them are translated appropriately. Then, the translation of $10(2.7 \%)$ figures of speech is categorized as less appropriate translation. And only 7 (1.8\%) figures of speech rendered inappropriately.

\section{Literature Review}

This section presents the negative expression in Indonesian and method of translation proposed by Newmark.

\section{Negative Expression in Indonesian}

What is meant by negation is the process, the act, or the way in denying or disavowing to thing. This process can be undergone by lingual or extra lingual. The lingual is also can be done by supra segmental (like special intonation for/tau/in Jakarta's dialect meaning "no"), and also segmental. This study focused on segmental negation, limited for sentences using negative devices (constituents).

Constituent that utter the negation made from free 
morpheme covers two groups, they are formal constituent that expresses the negation alone, and other constituents that support another negation. The first type of constituent is tidak or bukan. The second type of negative devices that not only as a negative device but also help another function like imperative are takkan, tiada, jangan, belum and tanpa. Jangan is a negative device in imperative sentence. Therefore, jangan is paraphrased with tidak boleh.

Semantically, those negative constituents has similarities in the ability of denying or disavowing thing. Even though the way in which they deny are different. In this case tidak, tiada and bukan are used as the scale to know the ability in denying or disavowing since they are very important negation in Bahasa Indonesia. Then, we considered the bound morphemes a-, awa-, de-, des-, dis-, in-, im-, I, non-, nir-, tan-, and tuna- are constituents which can be paraphrased to tidak, tiada atau bukan. Take look at the following illustration.

(i) amoral - tidak menyangkut moral

(not having moral)

(ii) awahama - tidak berhama (without hama)

(iii) deregulasi-peniadaan kelebihan peraturan (not having regulation)

(iv) desintegrasi-keadaan tidak bersatu (not unity)

(v) disorientasi-peniadaan keberorientasian (not having orientation)

(vi) inkonsisten - tidak konsistent (inconsistent)

(vii) impersonal - tidak personal (impersonal)

(viii) illegal - tidak legal (illegal)

(ix) irrasional - tidak rasional (irrational)

(x) niraksara - tidak beraksara (not having letters)

(xi) tanaktor - tidak beraktor (not having any actor)

(xii) tunanetra - tidak bernetra (blind)

\section{a. Standard Negation}

Standard negation is a negation that can be expressed in a base sentence or a minimal sentence, like a sentence with a single predicate or a single clause. The concept of standard negation is closely related to the basic function of negation. Universally the basis function of negative constituent is to negate verb and or another constituent followed it. The negation function such above is called standard negation (Givon 1984, in Sudaryono 1992: 39) called it neutral negation.

Special in Indonesian which has subject verb object (SVO) pattern, (Sudaryanto, 1983. in Sudaryono 1992: 39), standard negation is expressed by placing the negative constituent in left side of the verb or another constituent as predicate.

\section{b. Negation and Quantity}

Negation used to express contradictory and contrary opposition. Jespersen (1917, in Sudaryono 1992: 131) states nexal (sentential negation commonly states contradictory opposition and special (constituent) negation 
states contrary opposition, such the following example.

(1) a. John is coming

b. John is not coming

(2) a. John is happy

b. John is unhappy

But in certain context, those opposition are not clear. If the negated word is expressing quantity, then the negation is not having that contrary. What are meant by expression of quantity are those which has the meaning of scalar or gradable value (Horn, 1989 in Sudaryono 1992: 131), let's see the examples below.

(3) a. He reads three books in a year

b. He does not read three books in a year

Common definition will say (3) a. is contradictory to 3 (b). But if the fact that the subject (he) read more than three books, so, the two sentences are contrary, as the two sentency are equally wrong. This fact shows that there is an interaction between negation and quantity expression

\section{c. Negation and adverb}

Adverb is a word whose most frequent function is to specify the mode action of a verb (Christal in Bright, 1992, quoted by Thoyyibah, 2005: 37) in line with this, Kridalaksana, 1986: 79 (in Sudaryono 1992: 154) explained that adverb is a word which gives description to a verb, adjective or nomina predicative, or a sentences.

Based on the ability in collocating with tidak, an adverb can be subcategorized using two parameters, they are:
(1) $($ tidak + adverb $+\mathrm{x})$
(2) $\quad($ adverb + tidak $+\mathrm{x})$

Tak can also be used to negate an adverb, but, since tak and tidak have parallel position when they are combined with an adverb, the word tidak is considered as the representative of $t a k$.

\section{Methods of Translation}

Many translation methods are proposed by experts. What will be described here are 7 methods of translation proposed by Newmark (1988: 45-53). The description of the 7 translation methods below is his original words.

\section{a. Word-for-Word Translation}

This is often demonstrated as interlinear translation with the TL immediately below the SL words. The SL word-order is preserved and the word translated singly by their most common meanings, out of context. Culturally, words are translated literally. The main use of wordfor-word translation is either to understand the mechanics of the source language or to construct a difficult text as a pre-translation process.

\section{b. Literal Translation}

A faithful translation attempts to reproduce the precise contextual meaning of the original within the constraints of the TL grammatical structures. It "transfers" cultural words and preserves the degree of grammatical and lexical "abnormality" (deviation from the SL norms) in the translation. It attempts to be completely faithful to the attention and the textrealization of the SL writer. In other words we can say that in this translation, the constructions of 
grammar are converted to their closest TL equivalent but the lexical words are again translated singly.

\section{c. Semantic Translation}

Semantic translation differs from "faithful translation" only in as far as it must take more account of the aesthetic value (that is, the beautiful and natural sound) of the SL text, comprising on "meaning" where appropriate so that no assonance, word-play or repetition jars in the finished version. Further, it may translate less important cultural words by culturally neutral third or functional terms but not by cultural equivalents - une none repassant un corporal may become "a nun ironing a corporal cloth"- and it may take other small concessions to the readership. The distinction between "faithful" and "semantic" translation is that the first is uncompromising and dogmatic, while the second is more flexible, admits the creative exceptions to $100 \%$ fidelity and allows for the translator's intuitive empathy with the original.

\section{d. Communicative Translation}

Translation attempts to render the exact contextual meaning of the original in such a way that both content and language are readily acceptable and comprehensible to the readership. In the process of translation, it is possible for the translator to use more than one method since depends on the goal of the translation itself.

\section{e. Idiomatic Translation}

Idiomatic translation reproduces the "message" of the original but tends to distort nuances of meaning by preferring colloquialisms and idioms where these do not exist in the original.

\section{f. Adaptation}

This is the "freest" form of translation. It is used mainly for plays(comedies) and poetry; the themes, characters, plots are usually preserved, the SL culture converted to the TL culture and the text rewritten. The deplorable practice of having a play or poem literally translated and then rewritten by an established dramatist or poets has produced many poor adaptations, but other adaptations have "rescued" period plays.

\section{g. Free Translation}

Free translation reproduces the matter without the manner, or the content without the form of the original. Usually it is a paraphrase which is much longer than the original, a so-called "intra lingual translation", often prolix and pretentious, and not translation at all.

\section{Method}

As this research is conducted in analyzing specific element, which is negative sentences using negative devices, in the novel entitled Bumi Manusia, qualitative-descriptive was used. In this study, the discussion does not only dig up about the Indonesian and English negation but its translation from Indonesian to English as well.

As a descriptive-qualitative research, the key instrument of the present study is the researcher herself. This is in line with the 
statement by Bogdan and Biklen (1994: 4), "Qualitative research has actual setting as the direct source of the data and the researcher is the key instrument." Such study of syntax and translation demands particular knowledge of syntax, translation, and the novel itself. The researcher, therefore, spent a great deal of her time reading and understanding the related theories and concepts before collecting and analyzing the data.

In collecting the data, several steps were carried out to have a further analysis. They consist of reading the original text of Bumi Manusia and taking the notes on negations in Indonesian and finding English negations of the obtained Indonesian data in Max Lane's translation, This Earth of Mankind.

Having collected the data relating to the negations, they were analyzed and categorized into their kinds whether they belong to standard negation, negation and quantity, or negation and adverb. The researcher only focuses on the negation in simple sentence; so in this step, she also discards the negations in complex and compound sentences.

\section{FINDING AND DISCUSSION}

Below, will be displayed the finding of the present study, related to kinds of negations, strategies used by the translator and the appropriateness of the translation.

\section{FINDING}

\section{The Kinds of Negations}

Three chapters are taken as the sample of this research. 329 negations are found from the novel Bumi Manusia. They are chapters 1, 3 , and 5 and consist of 69 pages. The analyzed negations are negations in simple sentences. Table 4.1 summarizes types of negations and their frequencies found in the novel.

Table 4.1 Types of Negation Found in Bumi Manusia

\begin{tabular}{|l|l|l|}
\hline Types of Negation & Total & Percentage \\
\hline Standard Negation & 193 & $59 \%$ \\
\hline Negation and adverb & 99 & $30 \%$ \\
\hline Negation and quantity & 37 & $11 \%$ \\
\hline Total & 329 & $100 \%$ \\
\hline
\end{tabular}

From the table above we can see that, most of the negation pattern in the novel is standard negation which covers 193 (59\%). It can be said that the standard negation replaced the majority of the occurrence.

\section{Translation Strategies}

The author of the original novel Bumi Manusia, uses a lot of negations in his books. It can be seen from the 68 pages taken as the sample; the researcher can identify 329 negations. Various negation translation strategies are used by the translator to give similar or equivalent meaning or message from the sentences. All negations found in the novel and their translations are put in appendix 1,2 , and 3 . Table 4.2 
summarizes the translation strategies the Indonesian in the novel Bumi and their frequencies that have been Manusia into English. applied by the translator in rendering

Table 4.2 Strategies Applied in Translating Negation from Indonesian into

English in Bumi Manusia

\begin{tabular}{|c|c|c|c|}
\hline No & Strategies & Total & Percentage \\
\hline 1 & $\begin{array}{l}\text { Negation is reproduced or adopted by the target } \\
\text { language }\end{array}$ & 207 & $62.3 \%$ \\
\hline 2 & Negation is replaced or adapted by the TL negation & 13 & $3.9 \%$ \\
\hline 3 & Negation is converted to sense or literalized & 13 & $3.9 \%$ \\
\hline 4 & Negation is changed into negation and quantity & 32 & $9.7 \%$ \\
\hline 5 & Negation is changed into negation and adverb & 11 & $3.4 \%$ \\
\hline 6 & Negation is reproduced or adopted plus sense & 3 & $1.0 \%$ \\
\hline 7 & Negation is negation and quantity plus sense & 1 & $0.3 \%$ \\
\hline 8 & Negation is changed into standard negation & 47 & $14.9 \%$ \\
\hline 9 & $\begin{array}{l}\text { Negation is changed into standard negation plus } \\
\text { sense }\end{array}$ & 1 & $0.3 \%$ \\
\hline 10 & Negation is deleted & 1 & $0.3 \%$ \\
\hline & Total & 329 & $100 \%$ \\
\hline
\end{tabular}

The classification above is arranged from the least adjustment to the most. The discussion of above the table can be clearly read in point 4.2.2 on the next page.

\section{The Evaluation of the Negation Translation Appropriateness}

Various strategies are applied by the translator in rendering the meaning of negation in the novel Bumi Manusia from Indonesian into English. Those strategies determine the appropriateness of the translation of negation in it. The appropriateness of the translation of negation is based on the three criteria: accurate, clear, and natural. Accurate refers to the quality of re expressing the meaning $\mathrm{f}$ the original message as closely as possible in the target; clear means understandable; and natural refers to the smoothness, i.e the acceptability of the translation in the target language (Tursini, 2007:60).

To make a clear description, here, the translation results (see table 4.3) are put into three categories: (1) appropriate translation, (2) less appropriate translation, and (3) inappropriate translation.

Table 4.3 Evaluation Results of Indonesian Negation Translation in Bumi Manusia into English

\begin{tabular}{|l|l|l|}
\hline Evaluation & Total & Percentage \\
\hline Appropriate translation of negation & 308 & $93.6 \%$ \\
\hline Less appropriate translation of negation & 19 & $5.8 \%$ \\
\hline Inappropriate translation of negation & 2 & $0.6 \%$ \\
\hline
\end{tabular}




\section{DISCUSSION}

\section{Standard Negation}

As stated in chapter II, standard negation is negation that can be expressed in a base sentence or a minimal sentence, like a sentence with a single predicate or a single clause. There are 194 standard negation (59\%) identified from the sample taken in the novel Bumi Manusia. Here are some of the examples:

\section{1) Tidak+ verb}

Ia tidak berkata sesuatu pun. (Page 80) $\rightarrow$ She didn't say a word. (Page 57)

The above sentence is narrated by Minke when he ran to find May (a motherless young girl) who was shapely asleep on a wooden divan, without a sheet. Minke picked her up and kissed her with a feeling of mercy and love. Minke thought how poor this young girl was who lived without her mother's lve. The negation tidak in the above sentence is translated into didn't. The word tidak here occurs right before verb berkata (say). Thus, this negation belongs to standard negation which negates the verb berkata (say).

2) $T a k+$ verb

Aku tak percaya pada guna-guna (Page 81) $\rightarrow$ I don't believe in black magic. (Page 58)

In the above example, tak occurs as standard negation. It is clear the negation tak directly negates a single verb without any expression between tak (don't) and percaya (believe). That negation shows that the speaker does not have any trust to a black magic.

3) Tiada + verb

Hari ini aku tiada pulang dulu ke pemondokan. (Page 74) $\rightarrow$ I hadn't wanted to go straight back to my lodgings. (Page 54)

The expression of negation tiada which occurs directly before a verb in the above example is a standard negation. It has the same meaning as tidak or tak. The above statement shows that the speaker was not going home first by saying tidakpulangdulu. The word tiada negates the verb phrase pulangdulu.

4) Jangan + verb

Hanya jangan lupa kau pada pelajaran $m u$. (Page 78 ) $\rightarrow$ Only don't forget your studies. (Page 56)

Jangan (don't) is negation in imperative expression. Here, it negates the verb lupa (forget), the implication is that the speaker wants to remind the listener (in this case Jean who talks to Minke) not to forget his studies while he is busy selling Jean's paintings.

5) Belum $+\mathrm{S}+\mathrm{V}$ 
Gedung ini belum terkenal. (Page $190) \rightarrow$ I was not yet acquinted with the building. (Page 128)

In the above sentence, the standard negation is represented by the word belum which is translated into was ... yet in English. The negation belum express the thing which is not experienced yet. Here, it shows this occasion is the fort time for Minke to see and know the building. The building seems new to him.

6) Bukan + N

Putraku yang dulu bukan pembantah begini. (Page 193) $\rightarrow$ My son of the past wasn't rebel like this. (Page 130)

The negation bukan which occurs directly before the noun (in a nominal sentence) above belongs to a standard negation. Since the English sentence formation must be formed by $\mathrm{S}+$ $\mathrm{V}$, than the word bukan is translated into was not (not only not).

The negation bukan negates the noun pembantah. This utterance is narrated by Minke's mother who seems disappointed with the condition of Minke now. Minke's mother thought that her son is different. The son likes to talk back to his brother in an impolite way (according to Minke's brother and Minke's mother opinion).

\section{Negation and Adverb}

In Indonesian, some adverbs are combined with various negative devices. The negative devices which are combined with various adverbs found in the novel BumiManusia are tak, belum, tiada, tidak and takkan. There are 99 negations and adverbs $(30 \%)$ identified in the novel BumiManusia.

1) $T a k+$ perlu

Dugaan itu tak perlu lebih lama ditunggu kenyataannya.(Hal. 204). $\rightarrow$ That prediction didn't have long to wait before it was verified. (Page 137)

The above expression shows the negation tak which is followed by the adverb perlu. Perlu is an adverb meaning the need to. The English version of this negation and adverb is changed into standard negation which is translated into $\mathrm{Neg}+\mathrm{V}$; didn't have.

2) $T a k+$ pernah

Terus terang saja, aku tak pernah bertanya ini pada diri sendiri. (Hal. 212) $\rightarrow$ To be frank, I'd never asked myself such a question. (Page 142)

The negation tak is followed by the word pernah which is an adverb explaining the verb bertanya. If the adverb pernah occurs after the negation tak, it means that the activity bertanya has never been done before. Then, here it's translated into; I'd never. 


\section{3) Belum}

Belum+pernah

Jadi belum pernah dengar tentangnya? (hal 216) $\rightarrow$ So you've never heard about it? (Page 145)

In the above sentence, the negation and adverb is represented by the word belum + pernah, where belum is the negation and pernah is the adverb. Here the word belumpernah is adopted into 've never; where it its contracted version of have never.

This sentence is illustrated by Miss Miriam who gives a question about the association theory. Since Minke doesn't know about this. Then he replied Miriam, you are now my teacher; listening to this, Miriam produced the above sentence "jadibelumpernahdengartentangn ya?"

4) Tiada+ pernah

Pintu kamar itu memang tiada pernah terkunci. (hal. 149) $\rightarrow$ The door wasn't locked. (Page 101)

Here the negative expression which is used is tiada. In the above utterance the negation tiada is followed by the adverb pernah. It is translated into wasn't. The above sentence is produced by NyaiOntosoroh when she was telling the story to her daughter Annelis how her servant, Darsam, came into her room for the first and the last time.

\section{5) Tidak+ pernah}

Nyatanya tuan tidak pernah menjadikannya perkara. (hal. $144) \rightarrow$ The fact is that you never took the case to the court. (Page 97)

Here the expression of negation is tidak then it is followed by the adverb pernah. In the English version it is translated as never. The above expression is spoken by MauritsMellema to his father, Mr. Herman Mellema, related to the past events when Mr. Herman Mellema never brought the case of his wife's affair to the court.

\section{Negation and Quantity}

The relation between negation and quantity will occurs if the sentence conveys the meaning of how to differentiate the relative scope of the quantifier. Related to quantity, Payne (1985: 203-4) divides negation into negated quantifier as not many, not every and inherently negated quantifier as nothing, nobody, or no in no friend. In the novel BumiManusia negation and quantity is expressed in 37 times (37\%) which are represented by the negative devices tidak, tak and takkan.

\section{Tidak}

Tidak+ ber + noun

In Indonesian, tidak + ber + noun is equivalent to no + noun or inherently negated quantifier.

Makan kita malam itu tidak bersambal, hanya berlada. (hal. 
107) $\rightarrow$ There had been no chili paste with dinner that night, just a little pepper. (Page 74). (See appendix 3, page 151)

Here the tidak bersambal which shows quantifier is translated into no chili paste.

Tidak+ ada

Syukur tamu itu tidak ada. (hal. 117) $\rightarrow$ Thanks to be God, there never was. (Page 81)

The word tidak is the negative device, where here, it modifies the quantifier ada. In the English version it is translated into never.

2. $T a k$

Related to quantity, tak can negate the word of quantity if it is combined with some quantifiers. Here are some examples found in the novel Bumi Manusia.

a. Tak+ber + noun

Rasanya aku sudah tak berjiwa lagi seperti selembar wayang di tangan ki Dalang. (hal. 126) $\rightarrow$ I felt I had no soul anymore, like a shadow puppet in the hand of the puppet master. (Page 86)

In the above sentence, the word tak berjiwa is a negation and quantity expression. In the target language it is translated into no soul.

b. Tak+ada+ noun

Tak ada orang Jawa bersuara begitu. (hal 120) $\rightarrow$ No Javanese has a voice like that. (Page 83)
The expression taka da orang Jawa is a negation and quantity which is translated into no Javanese. The above utterance is produced by Nyai Ontosoroh when she was still so young and virgin. She still lived with her parents and one day there was a guess in strange voice. From his voice, she could recognize that the guess was not a Javanese.

a. Tak+ sebuah + pun

Tak sebuah pun dari bacaannya berbahasa melayu. (hal. 134) $\rightarrow$ None of this reading material was in Malay. (Page 91)

Sebuah in the above sentence is a quantifier meaning one. Then it is negated to be using the negative device tak. After it a particle pun is added to sebuah to emphasize that there is nothing available. The expression tak sebuah pun is equivalent to none. The above sentence is produced by Annelis when she described the condition of her mother's library at home.

3. Tak kan

Tak kan ada yang menolong kau. (hal. 122) $\rightarrow$ No one is going to help you. (Page 84)

The above expressed is narrated by Sanikem when she is given to Mr. Herman Mellema. She said to herself that no one is going to help her. The negative devices which is used here is takkan. It can be decomposed into 
takakan, meaning the negation to negate something in the future.

\section{Belum}

Belum ada rumah indah kita ini. (hal. 134) $\rightarrow$ We didn't have this beautiful house then. (Page 90)

Nyai Ontosoroh expressed the above sentence when she told Annelis, her daughter about her house. She said that she did anything, studying, and working hard and saving money before she had a lot of money to build her house. Here the expression of negation is in the form of belum. Then it is combined with ada to show a quantity. In the TL written didn't have or a standard negation.

\section{CONCLUSSIONS}

In accordance with the research problems arranged previously, this study then draw the conclusions as follows:

1. Based on the research analysis, of the 69 pages of the novel Bumi Manusia, 329 negation in simple sentences are identified. They are divided into three types: standard negation, negation and adverb, and negation and quantity. Related to their frequency of occurrence, this study presents the results which are arranged from the highest to the lowest; they are as follows: 193 standard negation (59\%), 99 negation and adverb (30\%), and 37 negation and quantity $(11 \%)$. This order of frequency explains that standard negation is the most important and widespread negation because of its use of disavowing or negating a thing. In a standard negation, the negative device occurs right before the verb without any additional word. This structure makes it as the simplest negation.

2. In translating the Indonesian negation in the novel Bumi Manusia, this study finds that strategies which have been applied are adopted from the seven strategies proposed by Newmark. In addition there are also found three strategies adapted from the seven strategies above. From 329 negation, 205 or $62.3 \%$ are reproduced or adopted into English, 13 negation or $4 \%$ are replaced or adapted by the TL negation; 13 negation or $4 \%$ are converted to sense or literalized; 32 negation or $9.7 \%$ are changed into negation and quantity; 11 negation or $3.3 \%$ are changed into negation and adverb; 3 negation or $1 \%$ are reproduced by the TL plus sense; 1 negation or $0.3 \%$ are replaced or adapted by the TL plus sense;49 negation or $14.8 \%$ are changed into standard negation; 1 negation or $0.3 \%$ is changed into standard negation plus sense and 1 negation or $0.3 \%$ is deleted. These findings indicate that the translator mostly applied the strategy of reproducing or adopting the same image of negation in the TL text. This is because many negation in the novel Bumi Manusia are similarly common and popular in English.

3. The translation of Indonesian negation in the novel Bumi Manusia into English has been done well. It 
can be concluded from the results of evaluation, which shows that from 329 negations 308 or $93.6 \%$ are translated appropriately. Furthermore, this study also finds that 19 translation of negation or $5.8 \%$ are categorized as less appropriate translation, and 1 translation of negation or $0.3 \%$ is rendered inappropriately.

\section{Bibliography}

Ary, Donald, Jacobs, Lucy, \& Razavieh, Asghar. 2002. Introduction to Research in Education. Belmont: Wadsworth.

Brisling, Richard W. 1976.Translation Application and Method. New York: Garender Press.

Carford, J.C. 1974. A Linguistic Theory of Translation. New York: Oxford University Press.

Depdikbud.1982. Kamus Besar Bahasa Indonesia. : Balai Pustaka.

Fawcett, Peter. 1997. Translation and Language: Linguistic Theories Explained. United Kingdom: St. Jerome Publishing.

Grundy, Peter. 2000. Doing Pragmatics. London: Arnold.

Haegeman, Lilianne. 2005. The Syntax of Negation. New York: Cambridge University Press.
Horn, L.R. 1978. Some aspects of negation, in Greenberg etc. (Eds). Universal of Human Languages, vol. 4, syntax. Stanford: Stanford University Press.

Kirk, Peter. 2002. Holly Communicative? Current Approaches to Bible Translation Worldwide (http://web.onetel.net.uk/ pet erkirk/Bible\%20Translation\% 20Holy\%20Communicative.d oc.accessed on January $4^{\text {th }}$, 2007)

Larson, Mildred L. 1984. MeaningBased Translation: A Guide to Cross Language Equivalence. USA: United State Press of America.

Leezenberg, Michiel. 2001. Contexts of Metaphor. Amsterdam: Elsevier Science Ltd.

Levinson, S. C. 1983. Pragmatics. New York: Cambridge University Press.

Liukkonen Petri. 2008. Pramoedya Ananta Toer (1925-2006). Amazon.com (online). (http://Kirjasto.Sci.fi/Pram.ht $\mathrm{m})$ retrieved on 22 January 2010.

Martinich. 2001. The Philosophy of Language. New York: Oxford University Press.

Miles Matthew and Hubberman A. Michael. 1984. Qualitative Data Analysis. California: SAGE Publications. 
Newmark, Peter. 1988. Approaches to Translation. New York: Oxford University Press.

Newmark, Peter. 1988. A Textbook of Translation. Hertfordshire: Prentice Hall International (UK) Ltd.

Nida, Eugene, A., and Taber, Charles R. 1969.The Theory and Practice of Translation. Leiden: E. J. Brill.

Raford, Andrew. 2003. Syntactic Theory and the Structure of English. United Kingdom: Cambridge University Press.

Sadtono, E. 1985. Pedoman Penerjemahan. Jakarta: Depdikbud, Pusat Pembinaan dan Pengembangan Bahasa.

Sperber, D. and Wilson, D. 1995 (2 $2^{\text {nd }}$ Edition). Relevance: Bahasan Teori \& Penuntun Praktis Menerjemahkan. Yogyakarta: Kanisius.

Sudaryono. 1993. Negasi dalam Bahasa Indonesia. Jakarta: Pusat Pembinaan dan Pengembangan Bahasa.

Suryawinata and Hariyanto. 2003. Translation: Bahasan Teori \& Penuntun Praktis Menerjemahkan. Yogyakarta: Kanisius.

The University of Sydney. 2007. Max Lane Indonesia Southeast Asia and International Affairs, (http://www.asia-pacificaction.org/glw/glw2006.htma cessed on June , 16 2007)
Toer, Pramoedya, Ananta. 2006. Bumi Manusia. Jakarta Timur: Lentera Dipantara.

Toyyibah. 2005. Syntactic Analysis of Arabic and English Negation in the Holy Qur'an and its Translation in English. Unpublished Thesis. Malang: Graduate Program of Malang State University.

Trochim, William M. K. 2006. Qualitative Validity. (www.socialresearchmethods. net/kb/qualval.htm accessed on November $3^{\text {rd }}, 2005$ ).

Tursini, Umi. 2007. The Translation of Figures of Speech in the Novel "Bumi Manusia" from Indonesian into English. Unpublished Thesis. Malang: Graduate Program in English Language Education.

Ur, Penny. 1996. A Course in Language Teaching. Great Britain: Cambridge University Press.

Wiersma, William. 1991. Research Methods in Education. USA: Division of Simon \& Schuster, Inc. 
Jurnal al-Tsaqafa Volume 13, No. 02, Juli 2016

Halaman ini sengaja dikosongkan 